\title{
Reproductive toxicity of neem seeds (Azadirachta indica) in male quail (Coturnix coturnix japonica)
}

\author{
Rayr Cezar de Souza Góis ${ }^{1}$ Leandro Alves da Silva ${ }^{1}$ Hélio Noberto de Araújo Júnior ${ }^{{ }^{*}}$ (D) \\ Jardel Bezerra da Silva ${ }^{1}$ Tânia Vasconcelos Cavalcante ${ }^{2}$ Robério Gomes de Olinda $^{3}$ iD \\ Geysa Almeida Viana ${ }^{1}$ Marcelle Santana de Araujo ${ }^{1}$ Gabriela Hémylin Ferreira Moura ${ }^{1}$ (D) \\ Iago Antônio Ananias da Silva ${ }^{1}$ Carlos Iberê Alves Freitas ${ }^{1}$ Jael Soares Batista ${ }^{1}$
}

${ }^{1}$ Centro de Ciências Agrárias, Universidade Federal Rural do Semi-Árido (UFERSA), 59625900, Mossoró, RN, Brasil. E-mail: helio.noberto@outlook.com. *Corresponding author.

${ }^{2}$ Centro de Ciências Agrárias, Departamento de Clínica Veterinária e Cirurgia, Universidade Federal do Piauí (UFPI), Teresina, PI, Brasil. ${ }^{3}$ Centro de Ciências da Saúde, Universidade de Fortaleza (UNIFOR), Fortaleza, CE, Brasil.

ABSTRACT: Considering that neem (Azadirachta indica A. Juss.) causes deleterious effects on fertility, the objective was to evaluate the effect of feeding quail (Coturnix coturnix japonica Linnaeus, 1758) of 90 days old with neem seeds on seminal quality, biometric parameters, and testicular morphometrics, as an experimental model. After the 30 day adaptation period to the experimental conditions, birds were randomly distributed in five treatments of neem seeds incorporated into feed, with 10 replicates: T1 (0\%), T2 (5\%), T3 (10\%), T4 (20\%) and T5 (40\%). After 60 days of receiving experimental rations, their semen was collected to evaluate the sperm quality, the birds were euthanized, and testes were submitted to biometric, histological, and histomorphometric evaluation. The data were evaluated by analysis of variance and later by Tukey test with a significance level of 5\%. The mean values of testicle weight, length, and width significantly decreased in T4 and T5, due degeneration of germinal epithelial cells. In these treatments, it occurred a significant increase $(P>0.05)$ in the average values of the tunica albuginea thickness and a significant reduction in the values of the seminiferous tubule diameter and the height of the germinal epithelium. In addition, the mean values of seminal volume, sperm concentration, sperm motility, vigor, and sperm viability were significantly reduced. Thus, the use of neem in bird feeding, as well as the use for therapeutic purposes, is questionable, considering its negative impact on reproduction. Key words: Azadirachta indica, experimental poisoning, birds, testicular changes, sperm quality.

Toxicidade reprodutiva da semente de neem (Azadirachta indica) em codorna macho (Coturnix coturnix japonica)

RESUMO: Considerando que o neem (Azadirachta indica A. Juss.) causa efeitos deletérios na fertilidade, objetivou-se avaliar o efeito da alimentação com sementes de neem sobre a qualidade seminal, parâmetros biométricos e morfometria testicular com codornas (Coturnix coturnix japonica Linnaeus, 1758) com 90 dias de idade, como modelo experimental. Após o período de adaptação de 30 dias às condições experimentais, as aves foram distribuídas aleatoriamente em cinco tratamentos de sementes de neem incorporadas na ração, com 10 repetições: T1 (0\%), T2 (5\%), T3 (10\%), T4 (20\%) e T5 (40\%). Após 60 dias de receber rações experimentais, seu sêmen foi coletado para avaliar a qualidade espermática, as aves foram sacrificadas e os testículos foram submetidos à avaliação biométrica, histológica e histomorfométrica. Os dados foram avaliados por análise de variância e mais tarde pelo teste de Tukey com um nível de significância de 5\%. Os valores médios do peso, comprimento e largura do testículo diminuíram significativamente em T4 e T5, devido à degeneração de células epiteliais germinativas. Nestes tratamentos, ocorreu um aumento significativo $(P>0,05)$ nos valores médios da espessura da túnica albugínea e uma redução significativa nos valores do diâmetro do túbulo seminifero e a altura do epitélio germinal. Além disso, os valores médios do volume seminal, concentração de esperma, motilidade espermática, vigor e viabilidade espermática foram significativamente reduzidos. Assim, o uso de neem na alimentação de aves, bem como o uso para fins terapêuticos, são questionáveis, considerando seu impacto negativo na reprodução. Palavras-chave: Azadirachta indica, intoxicação experimental, aves, alterações testiculares, qualidade espermática.

\section{INTRODUCTION}

Neem (Azadirachta indica A. Juss) is a tree species of the Meliaceae family, which is native to India and has been used for centuries for a wide range of purposes. It is currently cultivated in several countries in Africa, Australia, and Latin America
(SOARES FILHO et al., 2015). Because it is resistant to drought, it is tolerant to most soil characteristics, including shallow, dry, stony, and heavily leached sand. Neem was rapidly disseminated in the semiarid region of the Brazilian Northeast, and is now widely used in afforestation of streets, squares, parks, and gardens (AZEVEDO et al., 2015). 
Neem arouses interest because of its great versatility. The tree produces excellent quality timber, being used for reforestation, landscaping and combating desertification (PAES et al., 2011). In addition to potential use as an animal feed supplement, neem may even replace the feed in some cases (ASSUNÇÃO, 2016).

A large number of bioactive compounds are present in seed, leaf, flower, bark, and roots of neem, which guarantee great versatility in their use (OGBUEWU et al., 2009). The chemical composition of seeds presents on average $28.92 \%$ of dry matter, $6.87 \%$ crude protein and $16.97 \%$ ethereal extract (NASCIMENTO et al., 2014). The principle of greatest concentration found in the neem seed is azadirachtin, corresponding to approximately $40 \%$ of the oil (SHAFY $\&$ ZAYED, 2002), responsible for most of the biological effects (MOSSINI \& KEMMELMEIER, 2005).

The use of azadirachtin has been shown to have anti-nutritive, toxic, insect repellent, and contraceptive effects. It is considered a bioantistatic product of the highest quality, as potent as commercial insecticides, and it is biodegradable, thus avoiding contamination of the environment (GOVINDACHARI et al., 2000).

Several medicinal properties of azadirachtin and other bioactive components of neem have been described in the literature, such as antimicrobial (PAES et al., 2015), anti-inflammatory (ASSUNÇÃO, 2016), hepatoprotective (BRASIL, 2013), antitumor (SCHUMACHER et al., 2011), tick-killing (MICHELETTI et al., 2009), antiviral (SOARES FILHO et al., 2015) properties.

In addition, some studies have indicated that neem has a negative effect on the reproductive function of mammals because it promotes the decline of seminal parameters (volume and concentration of ejaculate and motility and morphological changes of spermatozoa), and has proven spermicidal activity and vaginal contraceptive effects (SILVA, 2010; BRASIL, 2013). It also interferes with the estrous cycle of females and early embryonic development and promotes abortion (SILVA, 2010).

Little is known about the toxicity of Indian neem in domestic and wild poultry. According to BRITO (2013); although, neem is recognized for its different properties and forms of use, the contraceptive potential cannot be ignored. OLIVEIRA (2009) warned of the possibility of neem causing sterility in some species of birds that feed on their seeds, since, in the Brazilian Northeast, this tree produces extensive quantities of seeds during dry season, when there is little availability of food.
Considering that neem causes deleterious effects on the fertility of mammals (AUTA\& HASSAN, 2016) and insects (CARVALHO et al., 2015) and that there is a possibility of the consumption of neem seeds to promote a negative effect on the reproduction of birds (MOHAN et al., 1997), the objective was to evaluate the effect of feeding quail (Coturnix coturnix japonica Linnaeus, 1758) with neem seeds on seminal quality, biometric parameters, and testicular morphometrics as an experimental model.

\section{MATERIALS AND METHODS}

For the study, 50 male quails (Coturnix coturnix japonica Linnaeus, 1758) with 90 days old and average weight of 150 grams, were kept in the poultry sector of the Federal Rural Semi-Arid University (UFERSA). The quails were kept in a galvanized wire cage with dimensions of $1.00 \mathrm{~m} \mathrm{x}$ $0.50 \mathrm{~m} \times 0.20 \mathrm{~m}$ high ( 6 birds/cage), equipped with a trough-type feeder and nipple-type fountain.

Animals were fed commercial with isoprotein, containing $20 \%$ crude protein, $2730 \mathrm{Kcal}$ metabolizable energy $\mathrm{kg}^{-1}, 3.4 \% \mathrm{Ca}^{2+}$, and water ad libitum. For the balance of the ration, tables of composition of ingredients proposed by ROSTAGNO et al. (2005), with the concern that when adding the different percentages of neem seeds in the experimental ration, the proportion of the ingredients were kept constant, in order to meet the nutritional requirements for laying quail.

The experimental design was completely randomized, with the birds distributed in five treatments, with ten replicates, and each animal was an experimental unit. After the 30 day adaptation period to the experimental conditions, the birds were randomly distributed in five treatments of neem seed incorporated into the feed: T1 $(0 \%)$, T2 (5\%), T3 (10\%), T4 (20\%), and T5 (40\%). Seeds were collected directly from the trees, in complete maturation state, and were subsequently submitted to forced air circulation at $35^{\circ} \mathrm{C}$ for seven days and then finely crushed in a shredder (Trapp ${ }^{\circledR}$ TRF400) to a granulometry of particles smaller than $0.6 \mathrm{~mm}$.

At the end of the experimental period, birds were euthanized using xylazine hydrochloride $(2 \%)$, dissociative anesthesia with ketamine hydrochloride $(10 \%)$, and injection of lidocaine hydrochloride in the foramen magnum. Subsequently, birds were weighed individually with the aid of a precision scale, and submitted to necropsy. Testicles were then removed from the carcass, evaluated macroscopically, and photographed when they presented significant findings. 
After 60 days of receiving the experimental rations, seminal characteristics were evaluated. For this purpose, the vas deferens of each bird were removed with a scalpel blade and anatomical tweezers and transferred to a Petri dish, where they were sectioned in the distal portion, and the semen was aspirated with a 1 $\mathrm{mL}$ syringe, according to the methodology described by GOPINGER et al. (2012). The volume of semen $(\mu \mathrm{L})$ in micropipettes, concentration $\left(\times 10^{6} \mathrm{~mL}^{-1}\right)$ in Neubauer's hematimetric chamber, motile spermatozoa (\%), and sperm vigor ( 0 to 5$)$ were measured. In addition, semen-containing smears stained with propidium iodide associated with the Hoechst 33258 dye were evaluated for sperm viability by fluorescence microscopy at a 200 fold increase, according to the method described by HARRISON \& VICKERS (1990).

To determine the biometric parameters, testes were weighed on an analytical scale and measured with the aid of a digital caliper, obtaining the values for weight, length, and width. The testes were then fixed in Bouin solution for $48 \mathrm{~h}$, and then stored in alcohol at $70 \%$. After fixation, the testicles were sectioned in the medial portions, and the fragments were submitted to dehydration in increasing concentrations of ethyl alcohol, diaphanized in xylol, and embedded in paraffin to make cutting in microtomes at $5 \mu \mathrm{m}$, which were stained by hematoxylin and eosin (HE). The histological sections obtained were observed under an optical microscope, and a descriptive analysis of histopathological alterations was performed.

For the morphometric study of the testicular parenchyma, the histological sections were evaluated using an optical microscope (OlimpusBX50), coupled to a digital camera. Fifty (50) fields were randomly photographed per slide, with a 200 -fold increase. The scanned images were analyzed using Image Pro-plus ${ }^{\circledR}$ software (Media Cybernetics-LP, USA). The following parameters were measured: tunica albuginea thickness (TAT), seminiferous tubule diameter (STD), and height of the germinal epithelium (HGE).

To evaluate possible differences between the treatments, the data obtained from the biometric parameters and testicular morphometric and seminal characteristics were submitted to analysis of variance (ANOVA), and the Tukey test was then applied at $5 \%$ of significance, using the program SAS 9.2 for Windows version 6.1.7601 (SAS Institute Inc ${ }^{\circledR}$ Cary, NC, USA).

\section{RESULTS}

The study of testicular biometric parameters showed that the mean values of weight, length, and width of the left and right testicles did not differ significantly $(\mathrm{P}>0.05)$ between $\mathrm{T} 1 \quad(0 \%)$, $\mathrm{T} 2(5 \%)$, and $\mathrm{T} 3(10 \%)$. There was a reduction in the mean values of these parameters in T4 $(20 \%)$ and T5 (40\%), and significant difference $(\mathrm{P}>0.05)$ in comparison to other treatments (Table 1).

The testis of the T1, T2 and T3 animals maintained a morphological aspect within the normality observed for the species (Figure 1). The testes of the T4 and T5 animals presented macroscopically reduced size, firm consistency, and yellowish color (Figure 2). Degeneration of the cells of the germinal epithelium characterized by the presence of cells with granulated, vacuolated eosinophilic cytoplasm with pyknotic nuclei was verified in the quails belonging to T4 and T5 (Figure 3).

Others important aspects observed in the testes were the reduction in the number of cells of the germ line, most of the seminiferous tubules containing only one layer of spermatogenic cells and absence of

Table 1 - Mean values and respective standard deviations of the biometric parameters of the right testicle (RT) and left testicle (LT), and gonadosomatic index of quails (Coturnix coturnix japonica Linnaeus, 1758) submitted to the diet containing different percentages of neem seeds (Azadirachta indica A. Juss).

\begin{tabular}{|c|c|c|c|c|c|}
\hline \multirow[t]{2}{*}{ Parameters } & \multicolumn{5}{|c|}{ - } \\
\hline & $0 \%$ & $5 \%$ & $10 \%$ & $20 \%$ & $40 \%$ \\
\hline Weight (g) RT & $2.48 \pm 0.39^{\mathrm{a}}$ & $2.38 \pm 0.40^{\mathrm{a}}$ & $2.10 \pm 0.23^{a}$ & $0.80 \pm 0.44^{b}$ & $0.77 \pm 0.76^{b}$ \\
\hline Weight (g) LT & $2.40 \pm 0.31^{\mathrm{a}}$ & $2.42 \pm 0.46^{\mathrm{a}}$ & $2.12 \pm 0.44^{\mathrm{a}}$ & $0.82 \pm 0.26^{\mathrm{b}}$ & $0.80 \pm 0.46^{\mathrm{b}}$ \\
\hline Length (mm) RT & $22.97 \pm 2.15^{a}$ & $21.85 \pm 2.82^{\mathrm{a}}$ & $20.02 \pm 2.88^{\mathrm{a}}$ & $11.58 \pm 1.25^{b}$ & $10.22 \pm 2.0^{b}$ \\
\hline Length (mm) LT & $22.84 \pm 2.29^{\mathrm{a}}$ & $21.74 \pm 2.44^{\mathrm{a}}$ & $20.09 \pm 0.43^{a b}$ & $11.82 \pm 1.86^{b}$ & $10.04 \pm 2.23^{b}$ \\
\hline Width (mm) RT & $14.97 \pm 0,86^{\mathrm{a}}$ & $13,33 \pm 1.50^{\mathrm{a}}$ & $13.81 \pm 1.30^{\mathrm{a}}$ & $7.81 \pm 1.44^{b}$ & $6.90 \pm 1.24^{b}$ \\
\hline Width (mm) LT & $14.52 \pm 1.49^{\mathrm{a}}$ & $13.00 \pm 1.42^{\mathrm{a}}$ & $12.90 \pm 0.26^{\mathrm{a}}$ & $7.23 \pm 1.34^{b}$ & $6.13 \pm 0.84^{b}$ \\
\hline
\end{tabular}

*Different lowercase letters on the same line indicate statistical difference at the level of 5\% probability for the parameters analyzed. 


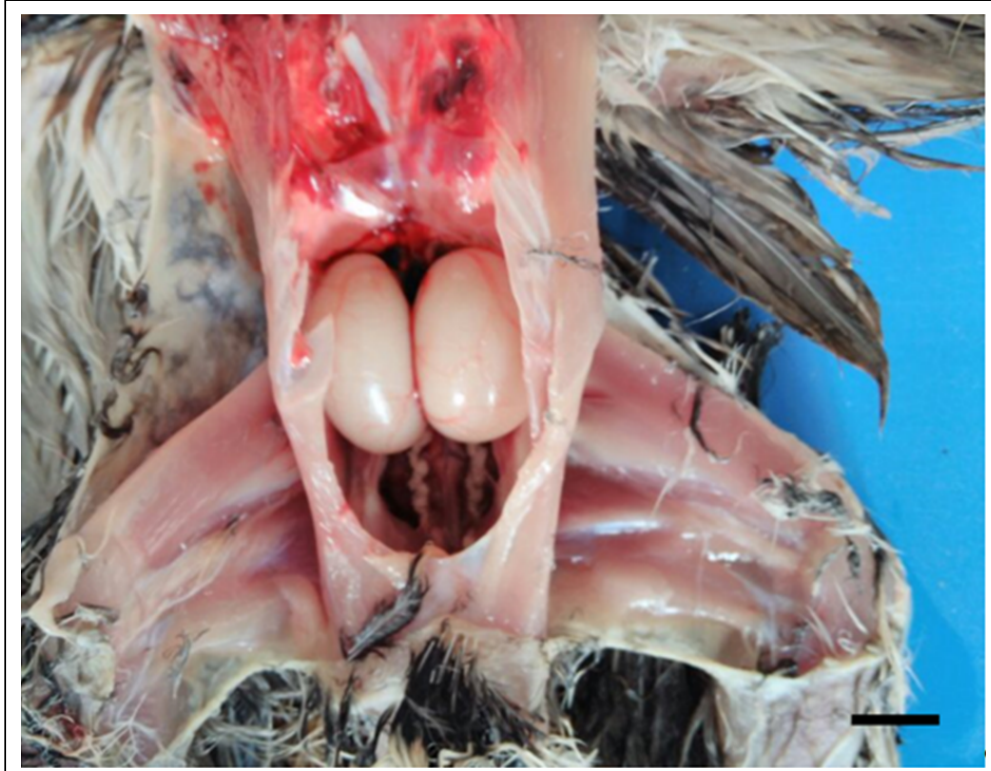

Figure 1 - Macroscopic aspect of the quail's testis (Coturnix coturnix japonica Linnaeus, 1758) with neem (Azadirachta indica A. Juss), T1, free diet, evidencing normal appearance and size. $\mathrm{Bar}=1 \mathrm{~cm}$.

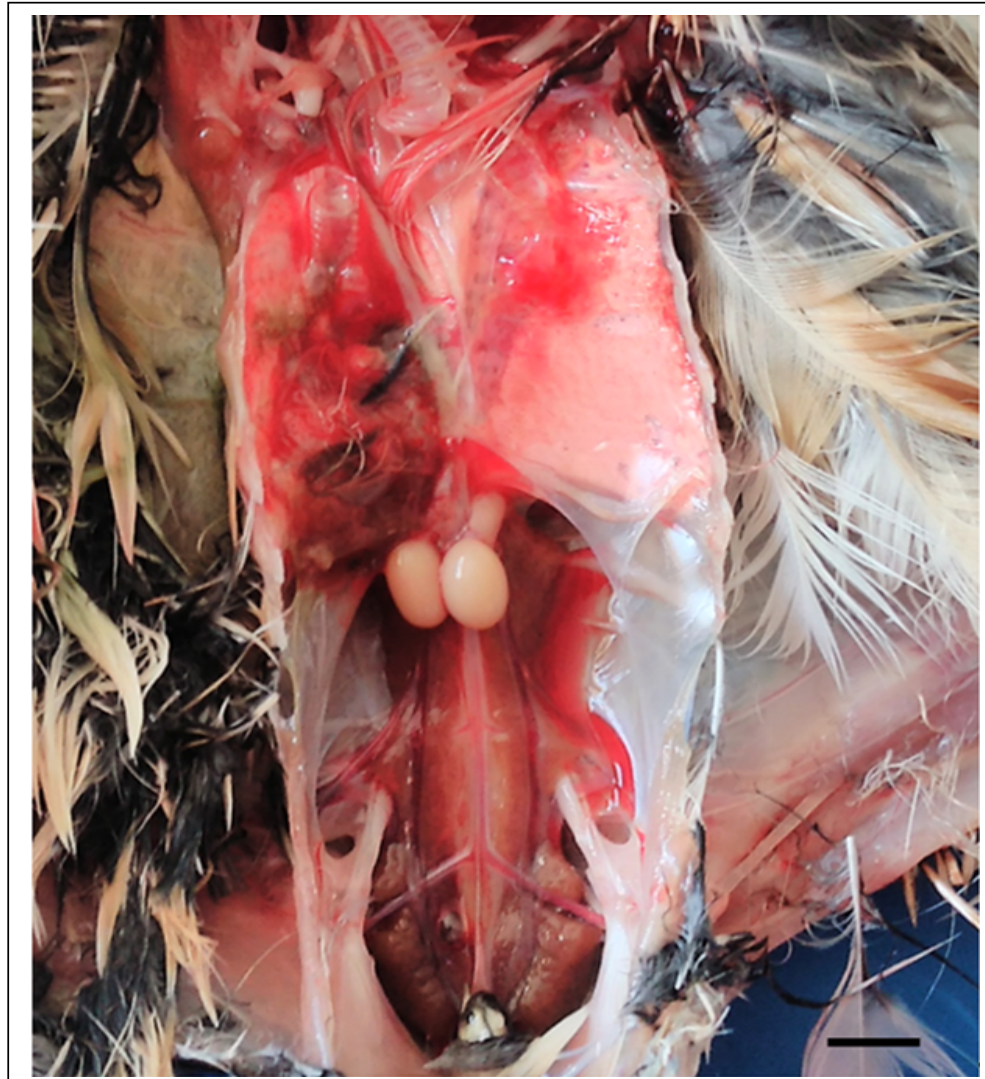

Figure 2 - Macroscopic aspect of the quail's testis (Coturnix coturnix japonica Linnaeus, 1758) submitted to the diet containing $40 \%$ (T5) of neem seeds (Azadirachta indica A. Juss) evidencing testicular atrophy. $\mathrm{Bar}=1 \mathrm{~cm}$. 


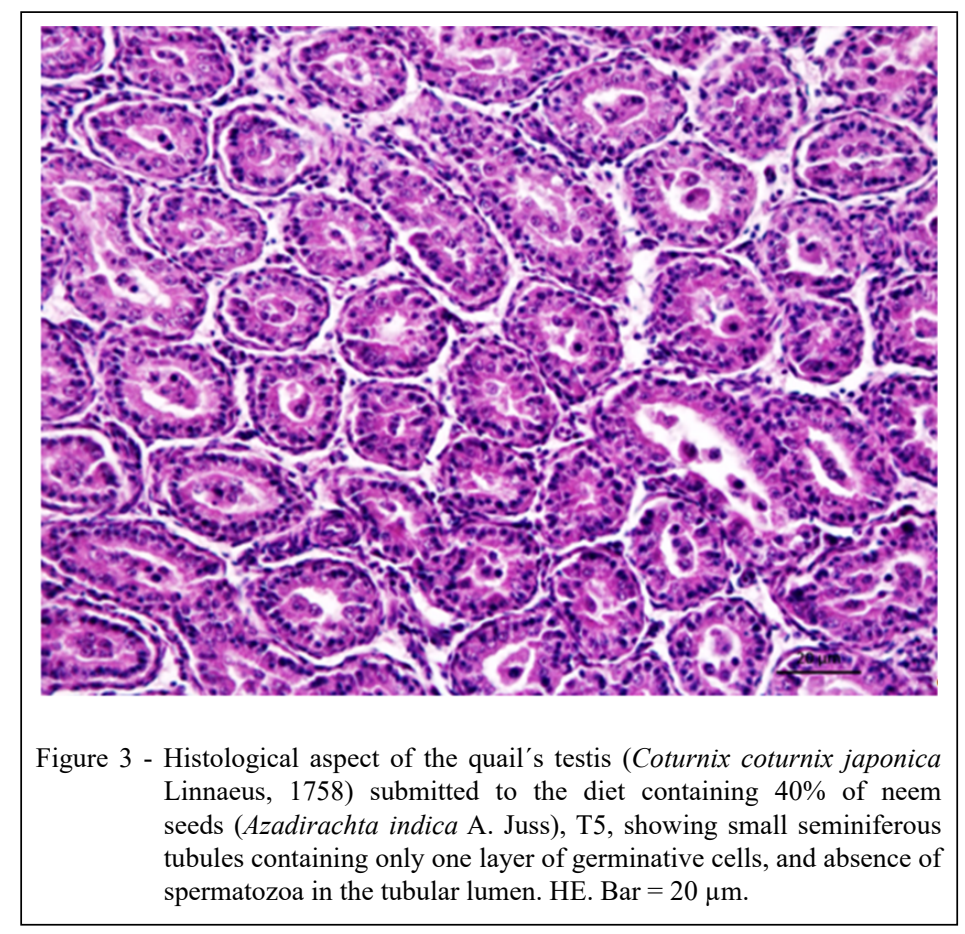

spermatozoa in the tubular lumen, besides the presence of cellular debris and macrophages in the lumen. Animals of other treatment groups presented testicular parenchyma with histological appearance within the normal range, with the presence of seminiferous tubules with unchanged cells of the spermatogenic lineage in different stages of maturation, in addition to a large number of spermatozoa in the tubular lumen (Figure 4).

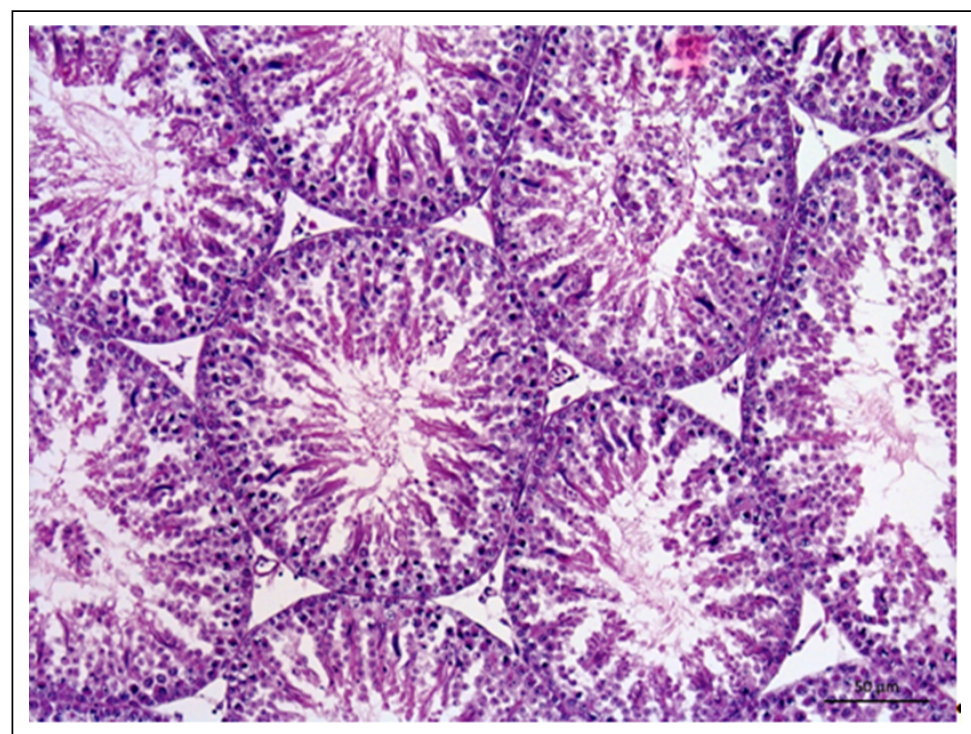

Figure 4 - Histological aspect of the quail's testis (Coturnix coturnix japonica Linnaeus, 1758) that received a neem (Azadirachta indica A. Juss) seedfree diet, showing normal-sized seminiferous tubules and unchanged germinative epithelium at different stages of maturation, with the presence of spermatozoa in the tubular lumen. HE. Bar $=50 \mu \mathrm{m}$. 
In the evaluation of the histomorphometric measurements of the testicles, it was T4 and T5 animals presented a significant increase $(\mathrm{P}>0.05)$ in the mean values of TAT, and a significant difference in comparison to the T1, T2, and T3 animals. The mean STD and HGE values did not differ significantly $(\mathrm{P}>0.05)$ between $\mathrm{T} 1, \mathrm{~T} 2$, and $\mathrm{T} 3$. However, a significant reduction in the values of these parameters was observed in T4 and T5 (Table 2).

The semen analysis revealed that the mean values of seminal volume, sperm concentration, sperm motility, and sperm vigor of quails belonging to T4 and T5 were significantly lower $(\mathrm{P}>0.05)$ when compared to values observed in T1, T2, and T3. Likewise, the reduction in sperm viability was significant in $\mathrm{T} 4$ and T5. The percentage of viable spermatozoa was $7.00 \%$ $\pm 3.59 \%$ (T4) and $6.00 \% \pm 3.59 \%$ (T5). However, in the T1, T2, and T3 animals, high percentages of viable spermatozoa were observed, representing $60.00 \%$ $\pm 3.59 \%$, $44.07 \pm 3.59 \%$, and $42.66 \% \pm 3.59 \%$, respectively (Table 3 ).

\section{DISCUSSION}

It is well documented in the literature that neem may present reproductive toxicity, as it negatively interferes in the reproduction of males and females (SURYAWANSHI, 2011). To date, are scarce studies that evaluate the occurrence of reproductive changes in birds that feed on neem seeds. Most of the studies on the subject are carried out in mammals and insects (AUTA \& HASSAN, 2016; CARVALHO et al., 2015); therefore, requiring a more detailed description involving histopathological and histomorphometric aspects of the testicular parenchyma of birds fed with different percentages of neem seeds.

The Japanese quail presents rapid gonadal development, sexual precocity, high fertility, high rusticity, and low space requirement for its confinement (PASTORE et al., 2012). Thus, we chose this species as a model for the study since the reproductive changes in the male quail caused by the consumption of neem seeds simulate what may occur with native birds that feed on neem seeds.

In domestic animals, one of the tools used to evaluate the reproductive potential in males and in the biometry of the testicular parameters. According to MACHADO et al. (2012) there is a positive correlation of weight, length and width of the testes with a production of spermatozoa and; therefore, with a fertility. Conversely, the reproductive capacity can be evaluated by the size of the testes (ETCHES, 1996).

This study showed that the addition of $20 \%$ and $40 \%$ of neem seeds in the diet resulted in a significant reduction in testis weight, length, and width. According to AIGBIREMOLEN \& ODIGIE (2018), the extract of the neonate can negatively affect the reproductive hormones in males, and thus causes reduction of testis weight is generally associated with the reduction in spermatogenesis and; therefore, in the reproductive capacity of the birds. Considering these observations, it is possible to suggest that the ingestion of percentages greater than $20 \%$ of neem seeds may influence the biometric testicular parameters that indicate infertility.

Histopathological analyses have been widely used to identify the nature, severity, and extent of lesions produced by bioactive compounds present in leaves, stems, fruit, and plant seeds (ASSIS

Table 2 - Mean values and respective standard deviations of tunica albuginea thickness (TAT), seminiferous tubule diameter (STD), and height of germ epithelium (HGE) of right testicle (RT) and left testicle (LT) of quails (Coturnix coturnix japonica Linnaeus, 1758) submitted to the diet containing different percentages of neem's seeds (Azadirachta indica A. Juss) measured in micrometers $(\mu \mathrm{m})$.

\begin{tabular}{|c|c|c|c|c|c|}
\hline \multirow[t]{2}{*}{ Variables } & 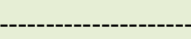 & ------------------'. & -Treatment------- & 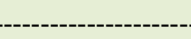 & 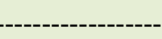 \\
\hline & $0 \%$ & $5 \%$ & $10 \%$ & $20 \%$ & $40 \%$ \\
\hline TAT (RT) & $11.27 \pm 1.60^{\mathrm{a}}$ & $11.60 \pm 1.83^{\mathrm{a}}$ & $11.78 \pm 0.744^{\mathrm{a}}$ & $19.93 \pm 0.88^{b}$ & $20.76 \pm 0.48^{b}$ \\
\hline TAT (LT) & $11.96 \pm 1.53^{\mathrm{a}}$ & $11.52 \pm 0.21^{\mathrm{a}}$ & $11.01 \pm 0.88^{\mathrm{a}}$ & $20.80 \pm 1.24^{b}$ & $21.46 \pm 2.40^{b}$ \\
\hline STD (RT) & $324.33 \pm 27.86^{\mathrm{a}}$ & $224.31 \pm 26.84^{\mathrm{a}}$ & $174.25 \pm 19.09^{\mathrm{ab}}$ & $108.85 \pm 12.87^{b}$ & $104.0 \pm 8.71^{b}$ \\
\hline STD (LT) & $318.46 \pm 8.68^{a}$ & $313.60 \pm 15.61^{\mathrm{a}}$ & $170.70 \pm 12.29^{\mathrm{ab}}$ & $100.16 \pm 10.58^{b}$ & $108.0 \pm 7.22^{b}$ \\
\hline HGE (RT) & $122.48 \pm 5.28^{a}$ & $109.30 \pm 3.98^{\mathrm{a}}$ & $74.27 \pm 4.21^{\mathrm{ab}}$ & $51.63 \pm 2.76^{b}$ & $51.22 \pm 6.75^{b}$ \\
\hline HGE (LT) & $118.41 \pm 3.74^{\mathrm{a}}$ & $113.78 \pm 2.11^{\mathrm{a}}$ & $73.22 \pm 3.95^{\mathrm{ab}}$ & $56.97 \pm 2.79^{b}$ & $54.67 \pm 4.24^{b}$ \\
\hline
\end{tabular}

*Different lowercase letters on the same line indicate statistical difference at the level of 5\% probability for the parameters analyzed. 
Table 3 - Mean and respective standard deviation of the quail's parameters (Coturnix coturnix japonica Linnaeus, 1758) submitted to the diet containing different percentages of neem seed (Azadirachta indica A. Juss).

\begin{tabular}{|c|c|c|c|c|c|}
\hline \multirow[t]{2}{*}{ Variables } & \multicolumn{5}{|c|}{ - } \\
\hline & $0 \%$ & $5 \%$ & $10 \%$ & $20 \%$ & $40 \%$ \\
\hline Volume $(\mu \mathrm{L})$ & $133.33 \pm 2.26^{\mathrm{a}}$ & $104.37 \pm 2.24^{\mathrm{a}}$ & $110.83 \pm 3.33^{a}$ & $26.00 \pm 2.10^{b}$ & $25.00 \pm 3.22^{b}$ \\
\hline Concentration $\left(\times 10^{6} \cdot \mathrm{mL}^{-1}\right)$ & $170.0 \pm 5.44^{\mathrm{a}}$ & $163.33 \pm 3.77^{\mathrm{a}}$ & $121.66 \pm 4.45^{\mathrm{a}}$ & $8.00 \pm 3.7^{b}$ & $8.00 \pm 4.21^{\mathrm{b}}$ \\
\hline Motility (\%) & $79.16 \pm 0.95^{\mathrm{a}}$ & $70.55 \pm 0.78^{a}$ & $53.33 \pm 0.68^{\text {a }}$ & $20.00 \pm 0.34^{b}$ & $18.00 \pm 0.93^{b}$ \\
\hline Vigor $(0-5)$ & $4.16 \pm 0.32^{\mathrm{a}}$ & $4.00 \pm 0.45^{\mathrm{a}}$ & $3.83 \pm 0.65^{\mathrm{a}}$ & $1.00 \pm 0.19^{\mathrm{b}}$ & $1.00 \pm 0.31^{\mathrm{b}}$ \\
\hline Viability (\%) & $60.00 \%$ & $36.44 \%$ & $42.66 \%$ & $7.00 \%$ & $6.00 \%$ \\
\hline
\end{tabular}

*Different lowercase letters on the same line indicate statistical difference at the level of 5\% probability for the parameters analyzed.

et al., 2010). In the present study, histopathological examination confirmed the toxic effect of the neem seeds on the testicular parenchyma, since the supply of $20 \%$ and $40 \%$ of neem seeds in the diet for 60 days promoted a marked degeneration of germinal epithelial cells and absence of spermatozoa in the tubular lumen. Degeneration of the seminiferous epithelium is a typical histological finding of testicular atrophic process, characterized by a reduction of the testicular biometric parameters, and is the most common and important cause of decline in male fertility (GARCIA, 2017). Thus, it should be noted that quails addition of $20 \%$ and $40 \%$ showed a significant reduction of testicular biometric parameters and testicular degeneration, as evidenced by histopathological examination.

The toxic effects of neem seed on the testicular parenchyma were described by DEHGHAN et al. (2006). The authors observed disorganization of seminiferous epithelium, nuclear pyknosis, and sperm agglutination in the epididymis and vas deferens of rats receiving $100 \mathrm{mg} \mathrm{kg}^{-1}$ of neem seed extract. Testicular histopathological changes in animals fed with neem seeds were also evidenced by DAFALLA et al. (2012), who recorded germ cell epithelial cell degeneration treated with $130 \mathrm{mg}$ $\mathrm{kg}^{-1}$ of aqueous neem seed extract for 14 days. The authors have concluded that neem seed extract has the adverse effect of antifertility, which occurs in a dosedependent manner, and that the use of the extract and its products for therapeutic purposes may not be considered safe.

The histomorphometric study of the testis reported that the quails fed with addition of $20 \%$ and $40 \%$ of neem seeds presented a significant reduction of STD and HGE, in addition to the significant increase of TAT. However, quails with addition of $0 \%, 5 \%$, and $10 \%$ presented testicular parenchyma with histological appearance within a normal range. Degeneration of the cells of the seminiferous tubule may result in loss of epithelial cells, resulting in decreased epithelial height, seminiferous tubule diameter, and testicular weight (SILVA et al., 2013). Thus, histomorphometric results obtained in the present study were in accordance with those verified in the biometric and histopathological analyses. The testicular histomorphometric parameters observed in the quails fed with addition of $20 \%$ and $40 \%$ of neem seeds were similar to those observed by AMOROSO et al. (2008) in Japanese quails that were at the end of reproductive activity. These authors observed that in this period, there was reduction of sperm cells and decrease in STD and HGE, accompanied by a significant increase of TAT and a rapid reduction of testicular weight.

The analysis of semen quality parameters revealed a significant reduction in seminal volume, sperm concentration, sperm motility, vigor, and sperm viability of quails with addition of $20 \%$ and $40 \%$, thus demonstrating that a significant increase in the percentage of neem seeds in the diet resulted in a negative effect on seminal quality.

Results obtained in the evaluation of the sperm viability of the present study reinforce the evidences of the reproductive toxicity of the neem in male quails. Sperm viability is one of the most commonly used parameters in the study of sperm quality evaluation and sperm fertilization capacity (OLIVEIRA et al., 2014). Sperm viability was evaluated by the sperm membrane integrity, by staining with propidium iodide associated with the Hoechst dye, which stained the spermatozoa with damaged membranes; and therefore, viable spermatozoa and blue sperm cells with an intact membrane. Thus, the percentage of viable spermatozoa was high with addition of $0 \%, 5 \%$ and $10 \%$, whereas the percentage 
of infeasible spermatozoa was low with addition of $20 \%$ and $40 \%$.

References in the current literature do not report the effect of neem seed feeding on seminal characteristics in birds. Nevertheless, the literature contemplates several studies in which they confirm the deleterious effect of the neem in the seminal characteristics in other species. BRITO (2013) describes dose-dependent action with a decreasing linear effect of seminal volume and motility of ovine spermatozoa, fed with oil extracted from the neem seed. EKALUO et al. (2010) observed that the number of spermatozoa was significantly reduced in albino rats treated daily intraperitoneally for 15 days with aqueous extract of neem leaves. AUTA \& HASSAN (2016) reported impaired sperm motility with the subcutaneous administration of $10 \mathrm{mg}$ of aqueous extract of neem trunk bark for 35 days in rats.

In this context, the addition of $20 \%$ and $40 \%$ of neem seeds in the quail diet for 60 days negatively impacted testicular biometric parameters, caused a pronounced degenerative germ cell disease, altered testicular morphometric parameters, and reduced semen quality. Thus, use of neem in bird feeding, as well as the use for therapeutic purposes, are questionable, considering its negative impact on reproduction.

\section{ACKNOWLEDGEMENTS}

The authors thank the Universidade Federal Rural do Semi-Árido (UFERSA), for the institutional support for this research. As well as the opportunity for essential student financial assistance provided by the Conselho Nacional de Pesquisa (CNPq) and Coordenação de Aperfeiçoamento de Pessoal de Nível Superior (CAPES), Brazil - Finance code 001.

\section{BIOETHICS AND BIOSSECURITY COMMITTEE APPROVAL}

This experiment was approved by the Animal Experimentation and Use Council of the Federal Rural Semi-Arid University under protocol no $23091.002959 / 2016-43$.

\section{DECLARATION OF CONFLICT OF INTERESTS}

The authors declare no conflict of interest. The founding sponsors had no role in the design of the study; in the collection, analyses, or interpretation of data; in the writing of the manuscript, and in the decision to publish the results.

\section{AUTHORS' CONTRIBUTIONS}

Góis, RCS and Freitas, CIA: conceived and designed experiments. Silva, LA; Silva, IAA and Moura, GHF: participated in the management of birds throughout the experiment. Araujo, MS: formulated the ration of the birds in experiment, as well as the accompaniment of the animals during the period. Cavalcante, TV; Viana, GA and Olinda, RG: participated in the laboratory analyzes as well as in the analysis of the results obtained. Batista, JS: responsible for the anatomopathological examination of the animals from the experiment. Evaluation of laboratory results and description of histological slides. Araújo Júnior, HN: participated in all processes of creation, structure, review and submission of the scientific article. All authors critically revised the manuscript and approved of the final version.

\section{REFERENCES}

AIGBIREMOLEN, A.A.; ODIGIE, M.O. Modulations of neem leaf extract on reproductive hormones of male Wistar rats. Journal of Bioengineering and Biomedical Science, v.8, p.1-4, 2018. Available from: <https://www.omicsonline.org/open-access/ modulations-of-neem-leaf-extract-on-reproductive-hormones-ofmale-wistar-rats-2155-9538-1000248-102131.html>. Accessed: May, 17, 2018. doi: 10.4172/2155-9538.1000248.

AMOROSO, L. et al. Spermatogenesis and testosterone levels influence on reproductive aspects of Japanese quails. Revista Brasileira de Zootecnia, v.37, p.61-66, 2008. Available from: <https://www.rbz.org.br/article/spermatogenesis-andtestosterone-levels-influence-on-reproductive-aspects-ofjapanese-quails/>. Accessed: May, 17, 2018. doi: 10.1590/ S1516-35982008000100008.

ASSIS, T.S. et al. Plant poisonings diagnosed in ruminants and horses and estimation of the economical losses in Paraíba. Pesquisa Veterinária Brasileira, v.30, p.13-20, 2010. Available from: <http://www.scielo.br/scielo.php?pid=S0100736X2010000100003\&script=sci_abstract $>$. Accessed: May, 17, 2018. doi: 10.1590/S0100-736X2010000100003.

ASSUNÇÃO, P.S. Use of the neem pie (Azadirachta indica) as antimicrobial in broiler rations. 2016. 39f. Dissertation (Postgraduate Program in Animal Science) - School of Veterinary and Zootech of the Universidade Federal de Goiás.

AUTA, T.; HASSAN, A.T. Reproductive toxicity of aqueous wood-ash extract of Azadirachta indica (neem) on male albino mice. Asian Pacific Journal of Reproduction, v.5, p.111-115, 2016. Available from: <https://www.sciencedirect.com/science/ article/pii/S2305050016000142>. Accessed: May, 17, 2018. doi: 10.1016/j.apjr.2016.01.005.

AZEVEDO, G.T.O.S. et al. Development of Indian neem seedlings under different levels of shading. Floresta Ambiental, v.22, p.249-255, 2015. Available from: <http://www.scielo.br/scielo. php? script $=$ sci_arttext\&pid $=$ S2 179-80872015000200249>. Accessed: May, 17, 2018. doi: 10.1590/2179-8087.091414.

BRASIL, R.B. Botanical aspects, traditional uses and potentials of Azadirachta indica (neem). Enciclopédia Biosfera, Centro Científico Conhecer, v.9, p.3252-3268, 2013. Available from: <http://www.conhecer.org.br/enciclop/2013b/ MULTIDISCIPLINAR/Aspectos.pdf>. Accessed: May, 17, 2018.

BRITO, O.S. Effects of neem oil (Azadirachta indica A. Juss) on reproductive and metabolic profile of male sheep. 2013. 74f. Thesis (Postgraduate Program in Zootech) - Universidade Federal de Viçosa. 
CARVALHO, S.S. et al. Systemic insecticidal effect of neem-based nanoformulations against Bemisia tabaci (Hemiptera: Aleyrodidae) biotype B in tomato. Bragantia, v.74, p.298-306, 2015 Available from: <http://www.scielo.br/scielo.php?pid=S000687052015000300298\&script $=$ sci_abstract $>$. Accessed: May, 17, 2018. doi: 10.1590/1678-4499.0404.

DAFALLA, M.B. et al. Biochemical and histological studies on the effects of Azadrichta indica seeds kernel extract on albino rats. International Journal of Medicinal Plant Research, v.1, p.82-92, 2012. Available from: <http://khartoumspace.uofk.edu/ handle/123456789/22186>. Accessed: May, 17, 2018.

DEHGHAN, M.H. et al. Histological evidence of male potent reproductive sites by Iranian botanical Azadiractha indica (neem) seed extract. International Journal of Molecular Medicine and Advance Sciences, v.2, p.7-15, 2006. Available from: $<$ http://medwelljournals.com/abstract/?doi=ijmmas.2006.7.15>. Accessed: May, 17, 2018.

EKALUO, U.B. et al. Effect of aqueous leaf extract of neem (Azadirachta indica) on the hormonal milieu of male rats. International Journal of Current Research, v.4, p.1-3, 2010. Available from: $<$ http://journalcra.com/article/effect-aqueous-leafextract-neem-azadirachta-indica-hormonal-milieu-male-rats $>$. Accessed: May, 17, 2018.

ETCHES, R.J. Avian Reproduction. Zaragoza: Acribia, 1996. 339p.

GARCIA, A.R. Testicular degeneration: is this a solved problem or a recurring dilemma?. Revista Brasileira de Reprodução Animal, v.41, p.33-39, 2017. Available from: <http://www.cbra. org.br/portal/downloads/publicacoes/rbra/v41/n1/p033-039\%20 (RB678).pdf $>$. Accessed: May, 17, 2018.

GOPINGER, E. et al. Effect of flaxseed oil in the diet of male quail (Coturnix coturnix coturnix) on semen characteristics and biometric evaluation of testicles. Revista Portuguesa de Ciências Veterinárias, v.111, p.177-181, 2012. Available from: $<$ http://www.fmv.ulisboa.pt/spcv/edicao/12_2012/177-181.htm>. Accessed: May, 17, 2018.

GOVINDACHARI, T.R. et al. Antifungal activity of some tetranortriterpenoids. Fitoterapia, v.71, p.317-320, 2000. Available from: <https://www.sciencedirect.com/science/article/ abs/pii/S0367326X99001550?via\%3Dihub>. Accessed: May, 17, 2018. doi: 10.1016/S0367-326X(99)00155-0.

HARRISON, R.A.P.; VICKERS, S.E. Use of fluorescent probes to assess membrane mammalian spermatozoa. Journal of Reproduction and Fertility, v.88, p.343-352, 1990. Available from: <https://www.researchgate.net/publication/21466075 Use_of_fluorescent_probes_to_assess_membrane_integrity_ in_mammalian_spermatozoa $>$. Accessed: May, 17, 2018. doi: $10.1530 /$ jrf.0.0880343

MACHADO, P.P. et al. Mathematical models and correlations of morphometric measurements of testicular and crossbred cattle fed slaughtered in São Luís, MA. Revista Brasileira de Reprodução Animal, v.36, p.51-61, 2012. Available from: $<$ https://pesquisa.bvsalud.org/bvs-vet/resource/pt/vti-8310 $>$. Accessed: May, 17, 2018.

MICHELETTI, S.M.F.B. et al. Plant extracts in control of Rhipicephalus (Boophilus) microplus (Canestrini, 1887) (Acari: Ixodidae) in laboratory. Revista Brasileira de Parasitologia
Veterinária, v.18, p.44-48, 2009. Available from: <http://www.scielo. br/scielo.php?script=sci_arttext\&pid=S1984-29612009000400008>. Accessed: May, 17, 2018. doi: 10.4322/rbpv.01804008.

MOHAN, J. et al. Antifertility effect of neem (Azadrichta indica) seed kernel meal in chickens. Asian Australasian Journal of Animal Sciences, v.10, p.609-613, 1997. Available from: <https:// www.ajas.info/journal/view.php?number=19228>. Accessed: May, 17, 2018. doi: 10.5713/ajas.1997.609.

MOSSINI, S.A.G.; KEMMELMEIER, C. The neem tree (Azadirachta indica): wide-ranging uses. Acta Farmacéutica Bonaerense, v.24, p.139-148, 2005. Available from: <http://www. latamjpharm.org/trabajos/24/1/LAJOP_24_1_7_1_3E9IR6431G. pdf $>$. Accessed: May, 17, 2018.

NASCIMENTO, A.L.S.; et al. Características morfoagronômicas e bromatológicas de acessos de nim indiano. In: Seminário de Iniciação Científica e Pós-Graduação da Embrapa Tabuleiros Costeiros, 2014, Aracaju. Anais... Brasília, DF: Embrapa, 2014.

OGBUEWU, I.P. et al. Effect of neem (Azadirachta indica) leaf meal on serum metabolite profiles of male rabbits. Revista UDO Agrícola, v.9, p.986-991, 2009. Available from: <http://www. bioline.org.br/pdf?cg09116>. Accessed: May, 17, 2018.

OLIVEIRA, B.M. et al. Fertility and uterine hemodynamic in cows after artificial insemination with semen assessed by fluorescent probes. Theriogenology, v.82, p.767-772, 2014. Available from: $\quad<$ https://www.sciencedirect.com/science/article/pii/ S0093691X14002854?via\%3Dihub>. Accessed: May, 17, 2018. doi: 10.1016/j.theriogenology.2014.06.007.

OLIVEIRA, R. The controversy of the neem of the region of the Inhamuns. Tauá: Tropical Garden, 2009. Available from: <http:// observatoriodosinhamuns.com/ 2009/11/04/o-nim-no-banco-dosreus/>. Accessed: Mar. 20, 2017.

PAES, J.B. et al. Yield and physical characteristics of neem (Azadirachta indica) and castor (Ricinus communis) oils. Floresta Ambiental, v.22, p.134-139, 2015. Available from: <http://www. scielo.br/scielo.php?pid=S2179-80872015000100134\&script $=$ sci abstract $>$. Accessed: May, 17, 2018. doi: 10.1590/21798087.047513 .

PAES, J.B. et al. Efficiency of neem (Azadirachta indica) and castor (Ricinus communis) oils on protection of Ceiba pentandra wood against xylophogous termites under feed preference assay. Revista Árvore, v.35, p.751-758, 2011. Available from: <http:// www.scielo.br/scielo.php?script $=$ sci abstract\&pid $=$ S0100$67622011000400020 \& \operatorname{lng}=\mathrm{pt \& nrm}=\mathrm{iso} \& \mathrm{t} \operatorname{lng}=\mathrm{en}>$. Accessed: May, 17, 2018. doi: 10.1590/S0100-67622011000400020.

PASTORE, S.M. et al. Overview of coturniculture in Brazil. Revista Eletrônica Nutritime, v.9, p.2041-2049, 2012. Available from: <https://www.nutritime.com.br/arquivos internos/artigos/180\%20-Panorama\%20da $\% 20$ coturnicultura_. pdf $>$. Accessed: May, 17, 2018.

ROSTAGNO, H.S. et al. Tabelas brasileiras para aves e suínos: composição de alimentos e exigências nutricionais de aves e suínos. 2nd. ed. Viçosa: Universidade Federal de Viçosa, $2005,186 \mathrm{p}$.

SCHUMACHER, M. et al. Anti-inflammatory, proapoptotic, and anti-proliferative effects of a methanolic neem 
(Azadirachta indica) leaf extract are mediated via modulation of the nuclear factor-kb pathway. Genes \& Nutrition, v.6, p.149-160, 2011. Available from: <https://link.springer.com/ article/10.1007\%2Fs12263-010-0194-6>. Accessed: May, 17, 2018. doi: 10.1007/s12263-010-0194-6.

SHAFY, S.A.; ZAYED, A.A. In vitro acararicidal effect of plant extract of Neem seed oil (Azadirachta indica) on egg, immature, and adult stages of Hyalomma anatolicum excavatum (Ixodoidea:Ixodidade). Veterinary Parasitology, v.106, p.89-96, 2002. Available from: <https://www.sciencedirect.com/science/ article/pii/S0304401702000237?via\%3Dihub>. Accessed: May, 17, 2018. doi: 10.1016/S0304-4017(02)00023-7.

SILVA, D.R. et al. Testis histologic and histomorphometric evaluations of cattle with digital dermatitis. Ciência Animal Brasileira, v.14, p.391-398, 2013. Available from: <http:// www.scielo.br/scielo.php?script $=$ sci abstract\&pid $=$ S 1809 -

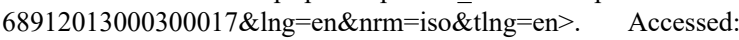
May, 17, 2018. doi: 10.5216/cab.v14i3.17709.
SILVA, V.C.L. Evaluation of the reproductive toxicity of Wistar rats submitted to the ingestion of ethanolic extract from neem leaves (Azadirachta indica A. Juss). 2010. 50f. Dissertation (Postgraduate Program in Animal Science) - Universidade Federal Rural de Pernambuco.

SOARES FILHO, C.V. et al. Neem oil (Azadirachta indica) in parasitological, haematological abd biochemical parameters of sheep naturally infected by gastrintestinal nematodes. Revista Brasileira de Saúde e Produção Animal, v.16, p.408-419, 2015. Available from: <http://www.scielo.br/scielo.php?pid=S151999402015000200015\&script=sci_abstract $>$. Accessed: May, 17, 2018. doi: 10.1590/S1519-99402015000200015.

SURYAWANSHI, J.A.S. Neem-natural contraceptive for male and female-an overview. International Journal of Biomedical Science, v.1, p.1-6, 2011. Available from: $<$ https://www.semanticscholar. org/paper/Neem-natural-contraceptive-for-male-and-female-anSuryawanshi/d40df43dc1193917a79a6a58e9dd715cf39e439f >. Accessed: May, 17, 2018. 